\title{
Seasonal variation of the calcifying green alga Phacotus lenticularis (Ehrenb.) Stein in water bodies under human influence (mid-western Poland)
}

\author{
Elżbieta Szeląg-Wasielewska' ${ }^{1}$, Maria Pajchrowska², Beata Mądrecka ${ }^{3}$, Justyna Józefiak ${ }^{1}$ \\ ${ }^{1}$ Adam Mickiewicz University, Faculty of Biology, Department of Water Protection, Umultowska 89, 61-614 Poznań, Poland, \\ e-mail:eszelag@uam.pl (corresponding author) \\ ${ }^{2}$ Poznan University of Life Science, Faculty of Horticulture and Landscape Architecture, Dąbrowskiego 159, 60-594 Poznań, Poland \\ ${ }^{3}$ Poznan University of Technology, Institute of Environmental Engineering, Faculty of Civil and Environmental Engineering, \\ Berdychowo 4, 60-965 Poznań, Poland
}

\begin{abstract}
The unicellular flagellates of the genus Phacotus, which form a solid calcite lorica by extracellular precipitation of calcium carbonate are some of the nanoplankters quite frequently occurring in hardwater ecosystems of the temperate zone. The aim of this study was to describe seasonal changes of Phacotus lenticularis populations in several types of water bodies (a glacial lake, small and shallow ponds, and a lowland river) in relation to some environmental parameters. All the water bodies are subject to multiple human pressure: recreation, fishing, agriculture, and urbanization. P. lenticularis individuals preserved in Lugol's solution were counted under an inverted microscope (after sedimentation in 14 or $9 \mathrm{ml}$ chambers), including both empty and filled loricae. Its populations differed both between seasons and between waters. High P. lenticularis abundance was mainly limited to the summer months. It was observed at temperatures above $19^{\circ} \mathrm{C}$ and $\mathrm{pH}$ values above 7.8 , in water characterized by quite high electrolytic conductivity $\left(>500 \mu \mathrm{S} \mathrm{cm}{ }^{-1}\right)$. Statistical analysis reveals two significant relationships between physicochemical parameters and the abundance of $P$. lenticularis. This suggests that in the investigated waters the biotic factors and processes are probably more important regulators of changes in the density of its population than nutrients.
\end{abstract}

Key words: green algae, Phacotus lenticularis, lorica

\section{Introduction}

Unicellular flagellates of the genus Phacotus (Chlorophyta, Chlamydomonadales) are mostly reported from hardwater lakes of the temperate zone, while the ecology of $P$. lenticularis (Ehrenb.) Stein has been subject to many studies, which have greatly increased our knowledge of this organism. The environmental role of $P$. lenticularis in freshwater habitats is comparable with that of coccolithophores in marine habitats (Schlege et al. 1998). Zoospores of $P$. lenticularis are surrounded with a lorica, composed of two symmetric lenticular parts. It is produced during zoosporulation and is incrusted with calcium carbonate, while the pattern of its mineralization depends on species and environmental factors (Dunlop and Walne 1993; Hepperle and Krienitz 1996; Schlegel et al. 2000; Gruenert and Raeder 2014). The precipitation of carbonate induced by phytoplankton, taking place in open water, is considered to be a mechanism preventing eutrophication. It is associated, e.g., with a decrease in phosphorus content and phytoplankton biomass (Koschel et al. 1983; Dittrich and Koschel 2002; Hamilton et al. 2009). Considering this, it can play an important role in water quality management in lakes and other water bodies. Only a few publications have reported on the dynamics of this species throughout the year, especially in the winter months (Szeląg-Wasielewska et al. 2016).

This study aimed to analyse seasonal changes in the population of $P$. lenticularis in various water bodies, in relation to selected environmental parameters, e.g. water temperature, $\mathrm{pH}$, electrolytic conductivity, and nutrients. The hypothesis that the number of $P$. lenticularis changes throughout the year in a wide range and the largest numbers of its cells will appear in the summer was verified. We took into account a medium-sized glacial lake, two small water bodies (ponds) of anthropogenic origin in an agricultural region and the middle section of a lowland, eutrophic river. These reservoirs are located close to each other in the city or its vicinity. 


\section{Study area}

Field research was conducted in four water bodies: Lake Strzeszyńskie and the river Warta in the city of Poznań, and two ponds located in the villages of Drwęsa and Dopiewo. All the water bodies are situated in the Poznań Lakeland, and according to the administrative division of Poland, in the communes of Poznan and Dopiewo in Greater Poland Province.

Lake Strzeszynskie lies in the north-western part of Poznan, in the catchment of the river Bogdanka, which is a left-bank tributary of the Warta. This glacial lake is medium-sized $\left(35 \mathrm{hm}^{2}\right)$, relatively deep $(\max 17.8 \mathrm{~m})$, with thermal stratification typical of the temperate zone. It is subject to human impact, mostly because of its use for recreation and angling introducing an additional load of nutrients (fish food) into the water (Kaźmierska 2015). The lake is affected by loading from both the direct catchment and the ditch Rów Złotnicki, which flows into the north-eastern part of the lake (Kaźmierska and Szeląg-Wasielewska 2015). Because of deteriorating water quality, many efforts have been made to restore the lake since 2011.

Ponds. The pond in Drwęsa is a small $\left(0.03 \mathrm{hm}^{2}\right.$, max depth $1.9 \mathrm{~m}$ ) artificial water body, used for recreation and storage of rainwater. No typical thermic stratification develops there, and the water level is highly variable, the lowest in late summer (Pajchrowska and Szpakowska 2014). The pond in Dopiewo is about 20fold larger $\left(0.62 \mathrm{hm}^{2}\right.$, max depth $\left.2.5 \mathrm{~m}\right)$ than the one in Drwęsa, and water flows through it. Its catchment comprises the village and farmland. The pond is used for angling, recreation, and fire protection. Among the studied water bodies, it is characterized by the highest trophic state, as reflected by high concentrations of chlorophyll- $a$ and total phosphorus (SzelągWasielewska et al. 2016).

Warta. The river in its middle part, in its gorge-like section, is classified as abiotic type 21 (large lowland rivers) (Mądrecka and Szeląg-Wasielewska 2017). It is a phytoplankton-rich river, with periodical water blooms caused by cyanobacteria, diatoms, and chlorophytes. Within the Greater Poland Province, the catchment area of the river is dominated by farmland (65\%). Intensive farming and the presence of many municipal and industrial water treatment plants in the catchment contribute to an increased trophic state of the Warta. Its water quality is also affected by the well-developed system of tributaries and the presence of many lakes (including oxbow lakes), fish ponds, and reservoirs in its catchment (Mądrecka 2015).

\section{Methods}

\section{Sampling of water}

Water samples for phycological and chemical analyses in Lake Strzeszyńskie were collected in 2016 from the surface layer of water, between January and December, once or twice a month (22 sampling dates). From the river Warta at the sampling station in Poznań near St. Roch Bridge samples were taken from the current in 2016, also from the surface water layer (17 sampling dates). In the ponds, field research was conducted in 2015. Samples of water were taken in the central part of the water bodies: from the pond in Drwęsa usually twice a month (26 sampling dates), while from the pond in Dopiewo once a month (12 sampling dates). The samples for phytoplankton analysis were preserved immediately at the site with Lugol's solution. At the same time, water samples were taken to determine the concentration of chlorophyll- $a$ and nutrients. Water temperature, dissolved oxygen, $\mathrm{pH}$, and electrolytic conductivity were measured directly at the sampling sites, using a YSI multiparameter sonde Professional Plus, Yellow Spring, Ohio, USA.

\section{Laboratory analyses}

In the laboratory, phytoplanktonic organisms were concentrated by settling in $9 \mathrm{~cm}^{3}$ and $14 \mathrm{~cm}^{3}$ chambers and analysed under an inverted microscope (MOD-2, Poland or CKX41, Japan) according to the method by Utermöhl (Wetzel and Likens 1991) at a magnification of $150 \times$ and $600 \times$. Photographic documentation was made at the Department of Water Protection, Adam Mickiewicz University, Poznan using the image analysis of cellsSens in the light microscope CKX 41 and in the Laboratory of Electron and Confocal Microscopy of the Faculty of Biology of the same university on a scanning electron microscope (SEM) Zeiss EVO40 (Germany). Chlorophyll- $a$ concentrations were determined spectrophotometrically after filtration through Whatman GF/F filters following extraction after 24 hours at $4^{\circ} \mathrm{C}$ in $90 \%$ acetone solution. Standard methods were used for analyses of concentrations of soluble reactive phosphorus (SRP), ammonium nitrogen, nitrate nitrogen, and total phosphorus (Hermanowicz et al. 1999). The statistical analyses of the results included linear correlation coefficients and the 95\% significance level was used.

\section{Results}

The studied water bodies varied greatly in water quality and trophic state during the year (Table 1). Except for the pond in Drwęsa, the water bodies were characterized by high electrolytic conductivity, usually markedly exceeding $500 \mu \mathrm{S} \mathrm{cm}^{-1}$. Its highest maximum 
Table 1. Physical, chemical, and biological characteristics of the surface water layer of the four investigated reservoirs, ND stands for not detectable

\begin{tabular}{|c|c|c|c|c|c|}
\hline Parameter & & Lake Strzeszyńskie & Pond in Dopiewo & Pond in Drwęsa & River Warta \\
\hline Temperature $\left[{ }^{\circ} \mathrm{C}\right]$ & $\begin{array}{l}\text { Range } \\
\text { Mean }\end{array}$ & $\begin{array}{c}0.9-23.0 \\
12.8\end{array}$ & $\begin{array}{c}1.1-27.2 \\
12.1\end{array}$ & $\begin{array}{c}1.19-21.3 \\
9.4\end{array}$ & $\begin{array}{c}3.0-22.9 \\
14.1\end{array}$ \\
\hline $\mathrm{pH}$ & $\begin{array}{l}\text { Range } \\
\text { Mean }\end{array}$ & $\begin{array}{c}7.4-8.5 \\
8.16\end{array}$ & $\begin{array}{c}7.6-10.9 \\
8.87\end{array}$ & $\begin{array}{c}7.0-8.7 \\
7.74\end{array}$ & $\begin{array}{c}7.78-8.8 \\
8.31\end{array}$ \\
\hline Conductivity $\left[\mu \mathrm{S} \mathrm{cm}^{-1}\right]$ & $\begin{array}{l}\text { Range } \\
\text { Mean }\end{array}$ & $\begin{array}{c}592-670 \\
612 \\
\end{array}$ & $\begin{array}{c}509-1068 \\
775\end{array}$ & $\begin{array}{c}350-512 \\
447\end{array}$ & $\begin{array}{c}516-769 \\
615\end{array}$ \\
\hline Dissolved oxygen [mg dm $\left.\mathrm{m}^{-3}\right]$ & $\begin{array}{l}\text { Range } \\
\text { Mean }\end{array}$ & $\begin{array}{c}4.7-16.1 \\
10.3 \\
\end{array}$ & $\begin{array}{c}7.0-17.0 \\
10.7\end{array}$ & $\begin{array}{c}1.8-12.8 \\
7.4\end{array}$ & $\begin{array}{c}7.8-12.4 \\
10.0\end{array}$ \\
\hline $\mathrm{NH}_{4}-\mathrm{N}\left[\mu \mathrm{g} \mathrm{N} \mathrm{dm}{ }^{-3}\right]$ & $\begin{array}{l}\text { Range } \\
\text { Mean }\end{array}$ & $\begin{array}{c}354-684 \\
525\end{array}$ & $\begin{array}{c}552-3142 \\
1557\end{array}$ & $\begin{array}{c}650-1168 \\
870\end{array}$ & $\begin{array}{c}168-800 \\
483\end{array}$ \\
\hline $\mathrm{NO}_{3}-\mathrm{N}\left[\mu \mathrm{g} \mathrm{N} \mathrm{dm}^{-3}\right]$ & $\begin{array}{l}\text { Range } \\
\text { Mean }\end{array}$ & $\begin{array}{c}36-1030 \\
271\end{array}$ & $\begin{array}{c}940-4440 \\
1300\end{array}$ & $\begin{array}{c}29-2690 \\
375\end{array}$ & $\begin{array}{c}81-250 \\
158\end{array}$ \\
\hline $\mathrm{SRP}\left[\mu \mathrm{g} \mathrm{P} \mathrm{dm}{ }^{-3}\right]$ & $\begin{array}{l}\text { Range } \\
\text { Mean }\end{array}$ & $\begin{array}{c}\text { ND-16 } \\
4\end{array}$ & $\begin{array}{c}38-588 \\
184\end{array}$ & $\begin{array}{c}14-101 \\
45\end{array}$ & $\begin{array}{c}76-202 \\
143\end{array}$ \\
\hline Total phosphorus [ $\left.\mu \mathrm{g} \mathrm{P} \mathrm{dm}^{-3}\right]$ & $\begin{array}{l}\text { Range } \\
\text { Mean }\end{array}$ & $\begin{array}{c}10-621 \\
102\end{array}$ & $\begin{array}{c}79-2527 \\
454\end{array}$ & $\begin{array}{c}33-2497 \\
385\end{array}$ & $\begin{array}{c}202-368 \\
264\end{array}$ \\
\hline Chlorophyll-a $\left[\mu \mathrm{g} \mathrm{dm}^{-3}\right]$ & $\begin{array}{l}\text { Range } \\
\text { Mean }\end{array}$ & $\begin{array}{c}1.1-11.4 \\
3.7\end{array}$ & $\begin{array}{c}4.3-865 \\
197.6\end{array}$ & $\begin{array}{c}10.9-379 \\
71.7\end{array}$ & $\begin{array}{c}8.2-151 \\
69.6\end{array}$ \\
\hline
\end{tabular}
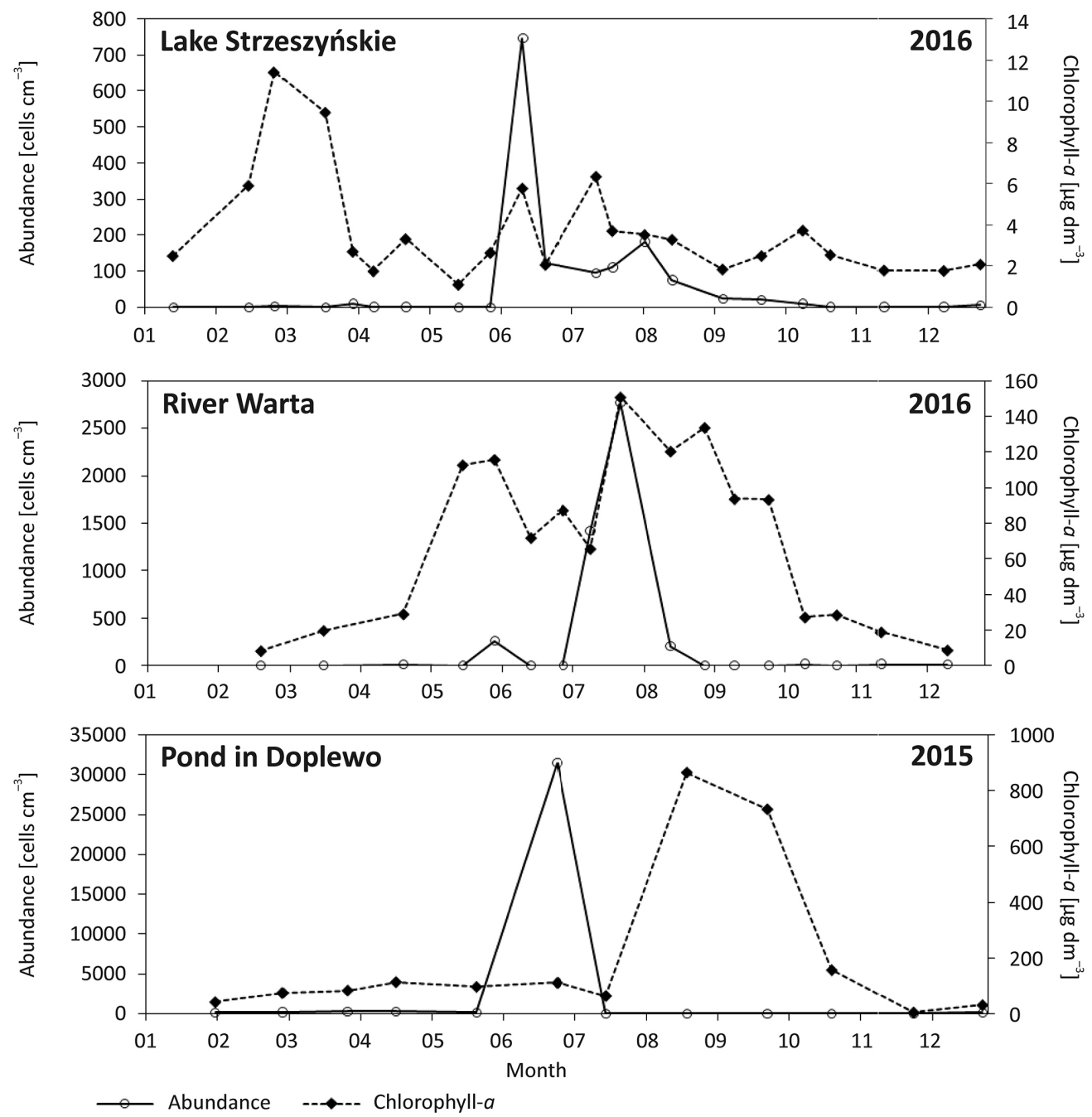

Fig. 1. Seasonal fluctuation in cell numbers of Phacotus lenticularis and chlorophyll-a concentrations in the investigated water bodies 
Table 2. Linear correlation coefficients between the abundance of Phacotus lenticularis and the investigated parameters; $p=$ significance level; ns = non-significant

\begin{tabular}{|l|c|c|c|}
\hline \multicolumn{1}{|c|}{ Parameter } & Lake Strzeszyńskie & Pond in Dopiewo & Warta River \\
\hline Temperature & $0.430(p=0.046)$ & $\mathrm{ns}$ & $\mathrm{ns}$ \\
\hline $\mathrm{pH}$ & $\mathrm{ns}$ & $\mathrm{ns}$ & $\mathrm{ns}$ \\
\hline Electrolytic conductivity & $\mathrm{ns}$ & $\mathrm{ns}$ & $\mathrm{ns}$ \\
\hline Dissolved oxygen & $\mathrm{ns}$ & $\mathrm{ns}$ & $0.579(p=0.015)$ \\
\hline Ammonium nitrogen & $\mathrm{ns}$ & $\mathrm{ns}$ & $\mathrm{ns}$ \\
\hline Nitrate nitrogen & $\mathrm{ns}$ & $\mathrm{ns}$ & $\mathrm{ns}$ \\
\hline SRP & $\mathrm{ns}$ & $\mathrm{ns}$ & $\mathrm{ns}$ \\
\hline Total phosphorus & $\mathrm{ns}$ & $\mathrm{ns}$ & $\mathrm{ns}$ \\
\hline Chlorophyll-a & $\mathrm{ns}$ & & \\
\hline
\end{tabular}

and mean values were recorded in the pond in Dopiewo. Similarly, water $\mathrm{pH}$, dissolved oxygen, and nutrients reached the highest maximum and mean values in this pond. In Dopiewo the mean chlorophyll- $a$ concentration of $198 \mu \mathrm{g} \mathrm{dm}^{-3}$ markedly contrasts with the low concentration of $3.7 \mu \mathrm{g} \mathrm{dm}^{-3}$ in the surface layer of water in Lake Strzeszyńskie. The mean total phosphorus level in the lake was $102 \mu \mathrm{g} \mathrm{dm}^{-3} \mathrm{P}, 2-3$-fold lower than in the other water bodies. Moreover, phosphates were scarce in the surface water in the lake for most of the year, as compared to the other studied water bodies. This can be linked with the conducted restoration of the lake, which consisted in precipitation of phosphorus from open water with coagulants, aeration of the hypolimnion with a wind-driven pulverizing aerator, and phosphorus inactivation in the bottom layer. Oxygen conditions were

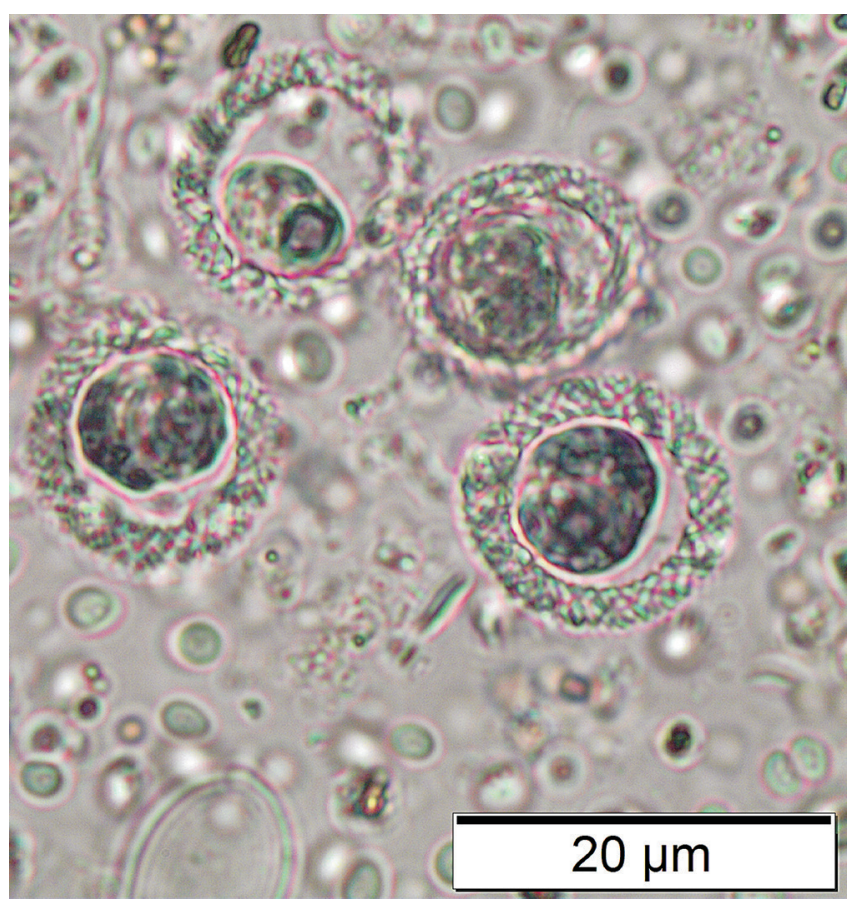

Fig. 2. Vegetative cells of Phacotus lenticularis in the pond in Dopiewo (light microscope image) good throughout the study period. Only sporadically in the pond in Drwęsa in summer they deteriorated because of the strong shading by leaves of trees reducing the amount of light for phytoplankton photosynthesis, as compared to the other studied water bodies.

Phacotus lenticularis was found in three out of the four studied water bodies, and its abundance in them varied from 0 to about $31.5 \times 10^{3}$ cells cm${ }^{-3}$. Differences between water bodies primarily concerned its population size (Fig. 1). In Lake Strzeszyńskie, P. lenticularis was recorded 17 times out of a total of 22 sampling dates, quite evenly distributed during the year. It was the most abundant in spring and summer. During its peak (747 cells $\mathrm{cm}^{-3}$ ) in mid-June, the vast majority of the population (84\%) were loricate monads (Fig. 2). Ten days later, the abundance of $P$. lenticularis was much lower, and only around $42 \%$ of loricae contained monads. Later, in early August, although the abundance of loricae increased to about 200 cells $\mathrm{cm}^{-3}$, the contribution of loricate monads was still small, about $33 \%$. Statistical analysis revealed a positive, significant correlation of the abundance of $P$. lenticularis with water temperature (Table 2). Among the taxa occurring together with $P$. lenticularis, the most numerous were cyanobacteria identified as members of two genera: Aphanocapsa and Aphanothece and green algae included Coelastrum and Eutetramorus species.

Monthly estimates of the abundance of $P$. lenticularis in the pond in Dopiewo show a wide range of its variation and most of the records were made in the first half of the year. In late June, its peak was observed, and empty loricae accounted for less than $1 \%$ of the population (Fig. 3, Fig. 4). Water temperature was then on average $19.1^{\circ} \mathrm{C}$ and $\mathrm{pH}$ was slightly alkaline (7.8). The most numerous in the phytoplankton were chroococcal bluegreen algae, chlorococcal green algae Chlorella spp., single diatoms (mainly Cyclotella meneghiniana Kützing) and Cryptomonas ovata Ehrenberg. In this pond, $P$. lenticularis was recorded again in late December, but most loricae (about 73\%), did not contain monads then, as in the first quarter of the year. Statistically, none 


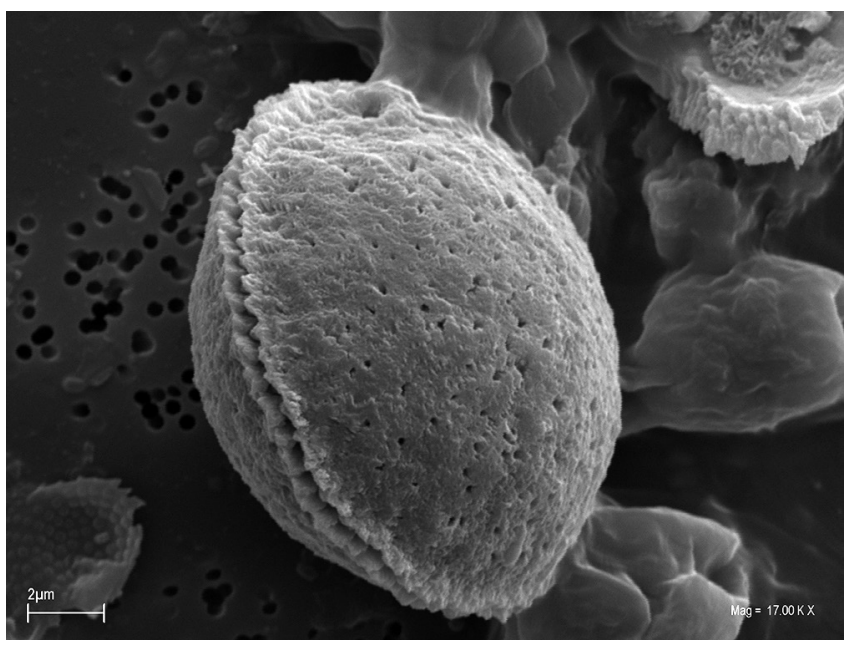

Fig. 3. Lorica of Phacotus lenticularis with flagellar pore depression and small pores on the lorica surface (SEM image)

of the analysed environmental parameters significantly affected the abundance of $P$. lenticularis. In the second pond, in Drwęsa, P. lenticularis was not found, although sampling frequency was more than twice as high there. The most numerous taxa in the phytoplankton of this pond were cryptophytes from the genus Cryptomonas (C. obovata Skuja, C. ovata Ehrenberg, C. phaseolus Skuja) and green algae from the genera Ankistrodesmus, Monoraphidium and Scenedesmus/Desmodesmus.

In the river Warta, P. lenticularis was recorded on 8 sampling dates (out of the total of 17, from February till December). Its abundance was the highest in mid- and late July: $1.42 \times 10^{3}$ cells $\mathrm{cm}^{-3}$, and $2.77 \times 10^{3}$ cells $\mathrm{cm}^{-3}$, respectively. Water temperature was then the highest, and $\mathrm{pH}$ slightly exceeded 8 (8.04 and 8.66 , respectively). The highest abundance of $P$. lenticularis coincided with the highest biomass of phytoplankton expressed as the concentration of chlorophyll-a (Fig. 1). In July, colonial diatoms of Fragilaria crotonensis Kitton, unicel-

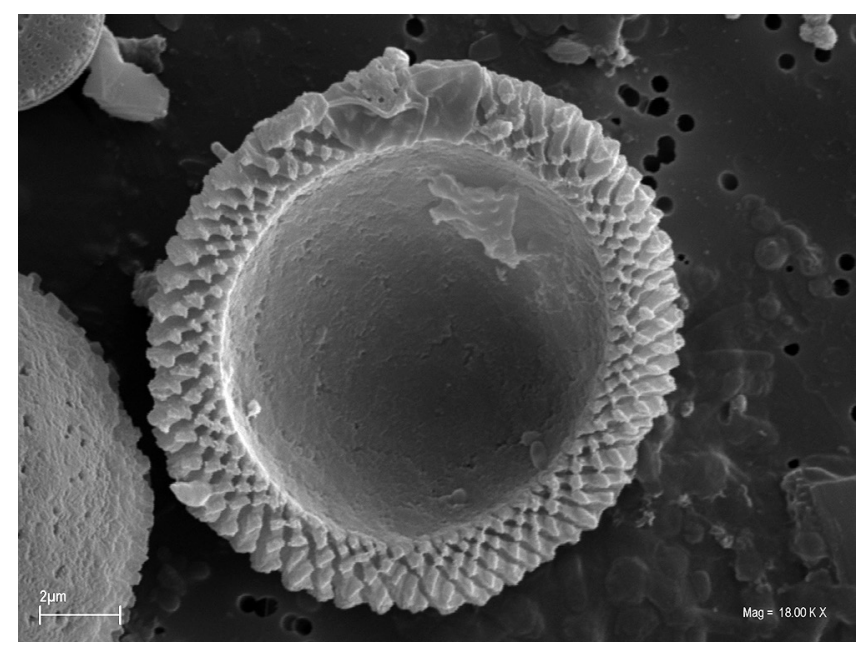

Fig. 4. Phacotus lenticularis - view into a lorica (SEM image) lular centric diatoms from genera: Stephanodiscus, Cyclostephanos, green algae (Chlamydomonas, Chlorella, Scenedesmus, Pediastrum) and cyanobacterium Microcystis aeruginosa (Kützing) Kützing co-occurred with $P$. lenticularis most frequently. In mid-August, when water temperature was nearly $3^{\circ} \mathrm{C}$ lower, its abundance was low: $0.09 \times 10^{3}$ cells $\mathrm{cm}^{-3}$. The abundance was positively but not significantly correlated with water temperature and significantly with ammonium nitrogen $(r$ $=0.579, p=0.015)($ Table 2$)$.

\section{Discussion}

Phacotus lenticularis is a nanoplankton species (13$17 \mu \mathrm{m})$, so in net plankton samples it can be easily overlooked. It has been found in the plankton of both standing and running waters, in virtually all trophic types of waters, while differences between water bodies primarily concerned its population size (Szeląg-Wasielewska et al. 2016). Generally it was more abundant in fertile and polluted waters. As reported by Bucka and Wilk-Woźniak (2002), this species is quite frequent in eutrophic ponds, lakes, and reservoirs. Padisák et al. (2009) classified it in the functional group of phytoplankton marked as $\mathrm{X}_{\mathrm{ph}}$ (earlier $\mathrm{Y}_{\mathrm{Ph}}$ ), including only one member. It is a small-celled organism, typical for calcium-rich waters, colonizing even periodical, sunlit alkaline waters.

In the phytoplankton of Lake Strzeszyńskie, changes in the abundance of $P$. lenticularis have already been documented (Szeląg-Wasielewska et al. 2016). The published results show that it varied widely between seasons and between years. In general, the summer months (June and July) were the most favourable for the development of this chlorophyte. Research on the phytoplankton of Lake Strzeszyńskie conducted in 2016 confirmed these trends. Correlation between the abundance of $P$. lenticularis and water temperature was significant at $p=0.048$. In the total phytoplankton biomass, P. lenticularis was rarely one of the major species. In Lake Strzeszyńskie it was accompanied by large numbers of small-sized and large-sized diatoms, smallsized cyanobacteria and cryptophytes, and coenobial chlorophytes (Szeląg-Wasielewska 2005, 2007).

In an earlier study (Szeląg-Wasielewska 2006), the estimated contribution of $P$. lenticularis to the total phytoplankton biomass in Lake Strzeszyńskie was quite high (up to 37\%). The lowest contribution of P. lenticularis to phytoplankton biomass was reported by Krienitz et al. (1993) from several northern German Baltic lakes and ponds and Stefaniak et al. (2007) from the hypertrophic Lake Swarzędzkie located in Poland (15 km east of Poznań), respectively $0.01-10.0 \%$ and $10.0 \%$. Also, in Lake Durowskie P. lenticularis was abundant, 
reaching densities of up to $1.5 \times 10^{3}$ cells $\mathrm{cm}^{-3}$. In contrast, it was not detected in the Struga Gołaniecka stream, which is a tributary of the lake, while in the central part of the lake basin its contribution to the total phytoplankton abundance and biomass exceeded 10\% (Gołdyn and Messyasz 2010). In other flowing waters, for example, the middle section of the River Radunia (Gołdyn 1989) and the in the phytoseston of a riverlake system in Drawieński National Park (Gołdyn and Szeląg-Wasielewska 2004) P. lenticularis was often noted.

In 2016 in the river Warta, P. lenticularis appeared frequently and reached a high abundance. In earlier years, it was rarely recorded at the sampling station in Poznań, and formed small populations. In contrast, other taxa developed large populations, and the dominant species in terms of phytoplankton abundance or biomass in the Warta were cyanobacteria, diatoms, and green algae (Szeląg-Wasielewska et al. 2016). The abundance of $P$. lenticularis was not significantly correlated with water temperature in the cited study, although in the Warta, as reported by Mądrecka (2015) the environmental factor most strongly affecting phytoplankton biomass was water temperature. The concentration of ammonium nitrogen, considered as the major source of nitrogen (Gumiński 1990) used for growth of algal cells, was significant $(p=0.015)$ for development of this chlorophyte.

Considering the two ponds sampled in this study, $P$. lenticularis was found in only one of them: the larger, throughflow pond in Dopiewo. Its density was higher there than in the other studied water bodies, and similar to the maximum reported by Krienitz et al. (1993) in the highly eutrophic/dimictic German Lake Haussee, also recorded in June: $32 \times 10^{3}$ cells $\mathrm{cm}^{-3}$. In 2014, the abundance of $P$. lenticularis in this pond was much lower, as it did not exceed $2 \times 10^{3}$ cells $\mathrm{cm}^{-3}$ (SzelągWasielewska et al. 2016). High concentrations of ammonium nitrogen, phosphorus, and high electrolytic conductivity of water indicate that the pond was polluted with municipal sewage and nutrients from the catchment dominated by farmland. It is also probable that calcium content was high in the pond, which would confirm the preference of $P$. lenticularis for hard waters rich in calcium. Many researchers suggest that the accumulation of calcium crystals within the lorica, in the case of a very high peak of $P$. lenticularis, may strongly affect the chemical composition of water (Stabel 1986; Schlegel et al. 1998; Dittrich and Koschel 2002; Hamilton et al. 2009).

Many years of investigations have shown that one of the studied water bodies - Lake Strzeszyńskie - has high seasonal variation in trophic state (from mesotrophic to eutrophic), while in summer its water turns whitish, which is associated with a remarkable decrease in Secchi depth (Kaźmierska 2015). The periodical whiting events are usually observed during peaks of P. lenticularis and picoplanktonic cyanobacteria in the epilimnion, mostly in July and August because they cause this phenomenon. Autotrophic phytoplankton are smallsized cells, but since they are very numerous their total surface of absorption is large and not uniform, which facilitates biomineralization and causes a deterioration of the light conditions in the water (Dittrich and Obst 2004).

\section{Conclusions}

The size of $P$. lenticularis populations differed both between seasons and between water bodies. High $P$. lenticularis abundance was strictly limited to the summer months. It was observed at temperatures above $19^{\circ} \mathrm{C}$ and $\mathrm{pH}$ values from 7.8 to 9.5 . The highest density $\left(3.2 \times 10^{4}\right.$ cells $\left.\mathrm{cm}^{-3}\right)$ was found in late June in the hypertrophic and hardwater pond in Dopiewo. In contrast, in the pond in Drwęsa, rich in nutrients and characterized by the lowest electric conductivity, P. lenticularis was not detected, even though the year before it was observed there. In the hardwater Strzeszyńskie Lake the abundance of $P$. lenticularis reached $0.8 \times 10^{3}$ cells $\mathrm{cm}^{-3}$ only in mid-June. Restoration treatments aimed at reducing phosphorus concentrations in this lake probably influenced the dynamics of its abundance, but the correlation was not statistically significant. Fertile running waters, represented by the Warta River, were characterized by an intermediate density of the species, which peaked in late July $\left(2.8 \times 10^{3}\right.$ cells $\left.\mathrm{cm}^{-3}\right)$. Statistical analysis reveals only two important relationships between $P$. lenticularis and environmental parameters. These were relations between the abundance of $P$. lenticularis and water temperature $(\mathrm{r}=0.430, p=0.046)$ and ammonium nitrogen $(\mathrm{r}=0.579, p=0.015)$. This indicates that biotic factors and processes are probably more important regulators of dynamic changes in the density of its population than nutrients. In the future, further studies are planned to examine other environmental parameters, mainly Ca-concentration.

\section{Acknowledgments}

We wish to thank the anonymous reviewers for making valuable suggestions for improving the manuscript.

\section{References}

Bucka H., Wilk-Woźniak E., 2002, Gatunki kosmopolityczne i ubikwistyczne wśród glonów pro- i eukariotycznych występujących w zbiornikach wodnych Polski południowej (A monograph of cosmopolitan and ubiquitous spe- 
cies among pro- and eukaryotic algae from water bodies in southern Poland), Zakład Biologii Wód im. Karola Starmacha PAN, Kraków, 233 pp (in Polish, English summary).

Dittrich M., Koschel R., 2002, Interaction between calcite precipitation (natural and artificial) and phosphorus cycle in the hardwater lake, Hydrobiologia 469(1-3): 49-57.

Dittrich M., Obst M., 2004, Are picoplankton responsible for calcite precipitation in lakes?, Ambio 33(8): 559-564.

Dunlop J.R., Walne P.L., 1993, Microarchitecture and mineralization in loricae of Phacotacean flagellates, Acta Protozool. 32: 237-243.

Gołdyn R., 1989, Algae in the seston of the middle section of the River Radunia, its tributaries and dam reservoirs (Northern Poland), Fragm. Flor. Geobot. 34(1-2): 201245.

Gołdyn R., Messyasz B., 2010, Ocena stanu ekologicznego Jeziora Durowskiego (Estimation of ecological status of Lake Durowskie) [typescript], Wydział Biologii UAM w Poznaniu, Poznań, 98 pp (in Polish).

Gołdyn R., Szeląg-Wasielewska E., 2004, Changes in the phytoseston of a river-lake system in Drawieński National Park, Oceanol. Hydrobiol. St. 3(2): 17-28.

Gruenert U., Raeder U., 2014, Growth responses of the calcite-loricated freshwater phytoflagellate Phacotus lenticularis (Chlorophyta) to the $\mathrm{CaCO}_{3}$ saturation state and meteorological changes, J. Plankton Res. 36(3): 630-640.

Gumiński S., 1990, Fizjologia glonów i sinic (Physiology of algae and cyanobacteria), Wydaw. UWr, Wrocław, 207 pp (in Polish).

Hamilton S.K., Bruesewitz D.A., Horst G.P., Weed D.B., Sarnelle O., 2009, Biogenic calcite-phosphorus precipitation as a negative feedback to lake eutrophication, Can. J. Fish. Aquat. Sci. 66(2): 343-350.

Hepperle D., Krienitz L., 1996, The extracellular calcification of zoospores of Phacotus lenticularis (Chlorophyta, Chlamydomonadales), Eur. J. Phycol. 31(1): 11-21.

Hermanowicz W., Dojlido J.R., Dożański W., Koziorowski B., Zerbe J., 1999, Fizyczno-chemiczne badanie wody i ścieków (Physical-chemical examination of water and wastewater), Wydaw. Arkady, Warszawa, 556 pp (in Polish).

Kaźmierska A., 2015, Wpływ antropopresji na bakterioplankton i autotroficzny pikoplankton w pelagialu Jeziora Strzeszyńskiego (Anthropogenic impact on bacterioplankton and autotrophic picoplankton in Strzeszyńskie Lake) [Dissertation], Wydz. Biologii UAM w Poznaniu, Poznań, 342 pp (in Polish, English summary).

Kaźmierska A., Szeląg-Wasielewska E., 2015, Evaluation of spatial and temporal variation in the quality of water: a case study of small stream in Poland, J. Ecol. Environ. Sci. 6(1): 137-142.

Koschel R., Benndorf J., Proft G., Recknagel F., 1983, Calcite precipitation as a natural control mechanism of eutrophication, Arch. Hydrobiol. 98: 380-408.

Krienitz L., Koschel R., Giering B., Casper S.J., Hepperle D., 1993, Phenomenology of organismic calcite precipitation by Phacotus in hardwater lakes and ponds of northeastern Germany, Verh. Int. Ver. Limnol. 25: 170-174.

Mądrecka B., 2015, Dynamika zmian fitoplanktonu w środkowym biegu rzeki Warty i jej wpływ na koncepcje uzdatniania wody (Dynamics of phytoplankton changes in the middle reaches of the river Warta and its impact on water treatment concepts) [Dissertation], Politechnika Poznańska, Poznań, 250 pp (in Polish, English summary).

Mądrecka B., Szeląg-Wasielewska E., 2017, Mass development of phytoplankton in the River Warta in Poznań (Poland) in the 21st centuary, Limnol. Rev. 17(2): 79-88.

Padisák J., Crossetti L.O., Naseli-Flores L., 2009, Use and misuse in the application of the phytoplankton functional classification: a critical review with updates, Hydrobiologia 621(1): 1-19.

Pajchrowska M., Szpakowska B., 2014, Assessment of occurrence microphytes and trophic status of small water body in the Wielkopolska Region (western Poland), Pol. J. Natur. Sc. 29(1): 17-33.

Schlegel I., Koschel R., Krienitz L., 1998, On the occurrence of Phacotus lenticularis (Chlorophyta) in lakes of different trophic state, Hydrobiologia 369/370: 353-361.

Schlegel I., Krienitz L., Hepperle D., 2000, Variability of calcification of Phacotus lenticularis (Chlorophyta, Chlamydomonadales) in nature and culture, Phycologia 39(4): 318-322.

Stabel H.H., 1986, Calcite precipitation in Lake Constance: chemical equilibrium, sedimentation, and nucleation by algae, Limnol. Oceanogr. 31(5): 1081-1093.

Stefaniak K., Gołdyn R., Kowalczewska-Madura K., 2007, Changes of summer phytoplankton communities in Lake Swarzędzkie in the 2000-2003 period, Oceanol. Hydrobiol. St. 36(Suppl. 1): 77-85.

Szeląg-Wasielewska E., 2005, Cyanobacteria in a slightly eutrophic lake: seasonal fluctuations and contribution to total phytoplankton, Oceanol. Hydrobiol. St. 34(Suppl. 3): $115-124$.

Szeląg-Wasielewska E., 2006, Trophic status of lake water evaluated using phytoplankton community structure - change after two decades, Pol. J. Environ. Stud. 15(1): 139-144.

Szeląg-Wasielewska E., 2007, Trophic state assessment based on late summer phytoplankton community structure: a case study for epilimnetic lake water, Oceanol. Hydrobiol. St. 36(3): 53-63.

Szeląg-Wasielewska E., Pajchrowska M., Mądrecka B., 2016, Biomineralizacja a jakość i trofia wód powierzchniowych (Biomineralization versus water quality and trophy of surface waters), [in:] Dymaczewski Z. et al. (eds.), Zaopatrzenie w wodę, jakość i ochrona wód (Water supply and water quality) Poznań: 395-412 (in Polish, English summary).

Wetzel R.G., Likens G.E., 1991, Limnological analyses, Springer-Verlag, New York, 391 pp. 